\title{
Estimation of genetic parameters of preweaning performance in the French Limousin cattle breed
}

\author{
MJ Shi, D Laloë*, F Ménissier, G Renand \\ Institut National de la Recherche Agronomique, Centre de Recherches \\ de Jouy-en-Josas, Station de Génétique Quantitative et Appliquée, \\ 78352 Jouy-en-Josas Cedex, France
}

(Received 11 June 1992; accepted 7 December 1992)

Summary - Direct and maternal genetic and environmental parameters of preweaning growth and conformation at weaning were estimated in the French Limousin beef cattle field recording program using the tilde-hat approach of Van Raden and Jung (1988) with a sire, maternal grandsire (MGS) and dam within MGS model. The numerator relationship matrix among bulls was included in the estimation. The data available after editing contained 169391 calves with performance records, from 43683 dams, 7265 sires, 5664 maternal grandsires and 1605 herds, for the years 1972-1989. The traits involved were: birth, 120-d and 210-d weights, average daily gains from birth to $120-\mathrm{d}$, from $120-\mathrm{d}$ to 210-d, from birth to 210-d, muscular development (MD) and skeletal development (SD) scores at weaning. Estimates ranged from 0.22 to 0.32 for additive direct heritabilities and from 0.06 to 0.16 for maternal heritabilities. Correlations between direct and maternal genetic effects for these traits were negative, ranging from -0.23 to -0.49 . Maternal permanent environmental effects were small for all traits, accounting for 5-9\% of the phenotypic variances for preweaning growth performance, and $3 \%$ and $4 \%$ for $\mathrm{MD}$ and $\mathrm{SD}$, respectively.

beef cattle / variance components / preweaning growth / conformation score / direct and maternal effects / field data

Résumé - Paramètres génétiques des performances avant sevrage en race bovine Limousine française. Les paramètres génétiques et environnementaux de la croissance avant sevrage et de la conformation au sevrage ont été estimés pour la race Limousine à partir des données du contrôle de performances en ferme. La méthode d'estimation de ces paramètres était la méthode tilde-chapeau de Van Raden et Jung (1988), avec un modèle père, grand-père maternel et mère intra-grand-père maternel. Les coefficients de parenté ont été inclus dans l'analyse. Les données analysées comprenaient 169391 veaux avec

* Correspondence and reprints 
performances nés entre 1972 et 1989, issus de 43683 mères, 7265 pères, 5644 grand-pères maternels et 1605 troupeaux. Les caractères considérés étaient : les poids à la naissance, $\grave{a} 120 j$ et $\grave{a} 210 \mathrm{j}$, les croissances de la naissance $\grave{a} 120 \mathrm{j}$, de $120 \mathrm{j}$ à $210 \mathrm{j}$ et de la naissance à $210 j$, les développements musculaire et squelettique. Les héritabilités estimées se situent entre 0,22 et 0,32 pour les effets directs et entre 0,06 et 0,16 pour les effets maternels. Les estimées des corrélations génétiques entre effets directs et maternels pour ces mêmes caractères sont toutes négatives et se situent entre $-0,23$ et $-0,49$. Les effets d'environnement permanent maternel sont faibles pour tous les caractères, contribuant à la variance phénotypique à hauteur de $5 \%$ à $9 \%$ pour les caractères de croissance avant sevrage, et de $3 \%$ et $4 \%$ pour les développements musculaire et squelettique.

bovins à viande / composantes de la variance / croissance avant sevrage / conformation / effets direct et maternel / contrôle de performances en ferme

\section{INTRODUCTION}

Knowledge of the magnitude of the variance and covariance components is critical for the genetic evaluation of animals and the development of sound breeding programs. For maternally influenced traits, direct as well as maternal effects need to be quantified. Direct and maternal effects seem to be correlated, but the sign and magnitude of this correlation is often a topic of some debate.

For the estimation of (co)variance components REML (Patterson and Thompson, 1971 ) is now the method of reference, due to its desirable properties, ie nonnegativity (Harville, 1977), ability to take account of selection (Sorensen and Kennedy, 1984; Werf and Boer, 1990). With large data sets, however, REML is almost unusable due to the need for inversion of the large coefficient matrix of the mixed model equations (Henderson, 1973) or the inverse of the complete covariance matrix of the vector of observations, despite a number of available numerical techniques (Meyer, 1990). Consequently, less expensive procedures with estimators reasonably close to REML solutions are desirable. Among approximate REML procedures like Henderson's method IV (Henderson, 1980), Schaeffer's method (Schaeffer, 1986) and the tilde-hat approach of Van Raden and Jung (1988), the last has been shown to yield estimates closest to REML solutions in data without or with little selection (Van Raden and Jung, 1988; Ouweltjes et al, 1988). Moreover, the tilde-hat approach of Van Raden and Jung (1988) does not require any inversion of a large matrix and is computationally easy even when the numerator relationship matrix and covariances between random effects are included (Manfredi, 1990; Manfredi et al, 1991). In the French Limousin breed, genetic trends for preweaning traits have been estimated by an animal model (Laloë, personal communication). It appears that there has been only limited selection practised in the population. With a small data set, Shi and Laloë (1991) showed that the tilde-hat approach led to estimates comparable to those of REML.

The objective of this study was to estimate direct and maternal genetic and environmental parameters for preweaning weights, growth rate and conformation at weaning for the French Limousin cattle breed using the tilde-hat approach of Van Raden and Jung (1988). 


\section{MATERIALS AND METHODS}

\section{Data description}

The French Limousin Breeding Association (France Limousin Selection) provided an extensive data set for estimation of direct and maternal (co)variances for the entire breed in France. Data consisted of 309530 records collected from 1972 to 1989.

Traits analysed were birth, 120-d, 210-d weights, average daily gain from birth to $120-\mathrm{d}\left(\mathrm{G}_{0-120}\right)$, from $120-\mathrm{d}$ to $210-\mathrm{d}\left(\mathrm{G}_{120-210}\right)$, from birth to $210-\mathrm{d}\left(\mathrm{G}_{0-210}\right)$, muscular development (MD) and skeletal development (SD) scores at weaning. The 120-d and 210-d weights were computed by interpolation between neighbouring records which were measured, at 3-month intervals, by technicians according to national rules (FNOCPAB-ITEB, 1983) Some weight records may be used in interpolation for both standard weights. Birth weight, declared by the breeder, was not used in this interpolation. MD and SD were linear functions of elementary scores given by experienced technicians.

Primary edits were conducted by eliminating: 1) calf weights and scores outside 3.5 SDs from the mean values of the corresponding traits within each sex;2) any calf with a common sire and maternal grandsire (MGS); and 3) calves born from a dam $<23$ months or $>16$ y old at calving, or later than the 12th parity. Further edits were performed to require, sequentially, sires to have at least 4 progeny, dams to have 2 progeny and MGS to have sired 2 dams, respectively. Herds were required to have a minimum of 8 records. In this way, the edited data set consisted of 169391 records. For average daily gain traits, only 168980 records were left after removal of records outside $3.5 \mathrm{SDs}$ from mean values by sex. As a result, 2 data files were used. Further statistics of the data sets are given in tables I and II.

Table I. Characteristics of the French Limousin data sets used for analyses.

\begin{tabular}{lcrrrr}
\hline Traits & No. of calves & Mean & SD & $\begin{array}{c}\text { Minimum } \\
\text { value }\end{array}$ & $\begin{array}{c}\text { Maximum } \\
\text { value }\end{array}$ \\
\hline Weights (kg): & & & & & \\
$\quad$ Birth weight & 169391 & 38.0 & 3.5 & 26.0 & 50.0 \\
120-d weight & 169391 & 158.5 & 20.8 & 92.0 & 232.0 \\
210-d weight & 169391 & 251.1 & 33.7 & 148.0 & 372.0 \\
Average daily gains (g/d): & & & & & \\
$\mathrm{G}_{0-120}$ & 168980 & 1004 & 165 & 408 & 1683 \\
$\mathrm{G}_{120-210}$ & 168980 & 1030 & 197 & 344 & 1844 \\
$\mathrm{G}_{0-210}$ & 168980 & 1015 & 155 & 505 & 1610 \\
Conformation (total score / 100): & & & & \\
$\quad$ Muscular development & 169391 & 60.0 & 8.0 & 35.0 & 87.0 \\
$\quad$ Skeletal development & 169391 & 60.3 & 6.5 & 40.0 & 80.0 \\
\hline
\end{tabular}


Table II. Number of levels and number of records by effects.

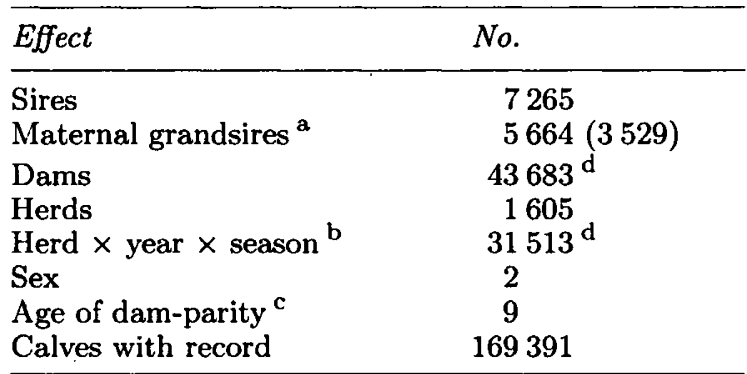

${ }^{a}$ Bulls identified at both sire and maternal grandsire $;{ }^{b} 6$ bimester seasons were identified (Jan to Dec by 2-month intervals); ${ }^{c} 9$ age of dam-parity groups were defined according to observed trends; 4 levels for the first parity according to the age of dam (23-29, 30-35, 36-39 and 40-48 month old) and 5 levels for the later parities (2nd, 3rd, 4th-7th, 8th-9th and 10th-12th); ${ }^{\mathrm{d}} 43682$ dams and 31469 herd-year-season levels for average daily gain traits.

\section{METHODS}

A sire, MGS and dam within MGS model was used for estimating the (co)variance components of the assumed maternally influenced traits. The model in matrix notation was:

$$
\mathbf{y}=\mathbf{X b}+\mathbf{Z}_{1} \mathbf{u}_{1}+\mathbf{Z}_{2} \mathbf{u}_{2}+\mathbf{Z}_{3} \mathbf{u}_{3}+\mathbf{e}
$$

where:

$\mathbf{y}=$ vector of observations;

$\mathbf{b}=$ vector of unknown fixed effects, including herd-year-season, sex and parity;

$\mathbf{u}_{1}, \mathbf{u}_{2}$ and $\mathbf{u}_{3}=$ vectors of unknown random effects for sire, MGS and dam within MGS effects, respectively;

$\mathbf{e}=$ vector of random residual effects;

$\mathbf{Z}, \mathbf{Z}_{1}, \mathbf{Z}_{2}$ and $\mathbf{Z}_{3}=$ known matrices relating records to the fixed and random effects in the model.

Identification and distribution of the number of levels for the fixed effects are reported in table II.

The expectations and variance-covariance structure of the effects of the model were assumed to be:

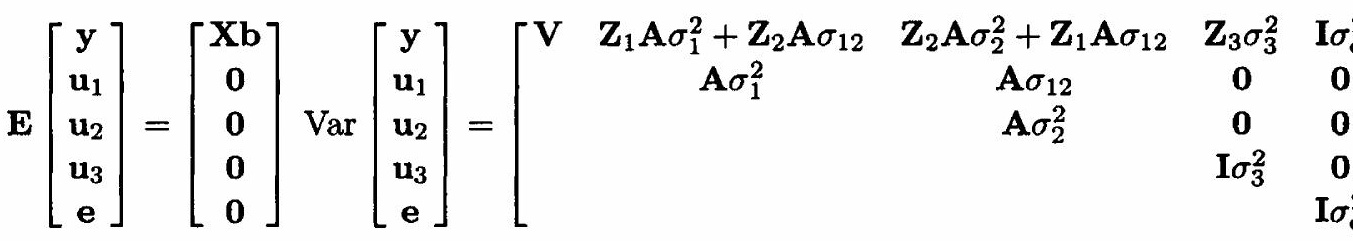

where:

$$
\mathbf{V}=\mathbf{Z}_{1} \mathbf{A} \mathbf{Z}_{1}^{\prime} \sigma_{1}^{2}+\left(\mathbf{Z}_{1} \mathbf{A} \mathbf{Z}_{2}^{\prime}+\mathbf{Z}_{2} \mathbf{A} \mathbf{Z}_{1}^{\prime}\right) \sigma_{12}+\mathbf{Z}_{2} \mathbf{A} \mathbf{Z}_{2}^{\prime} \sigma_{2}^{2}+\mathbf{Z}_{3} \mathbf{Z}_{3}^{\prime} \sigma_{3}^{2}+\mathbf{I} \sigma_{\mathbf{e}}^{2}
$$


$\sigma_{1}^{2}, \sigma_{2}^{2}, \sigma_{3}^{2}$ and $\sigma_{\mathbf{e}}^{2}=$ variances of sires, MGS, dam within MGS and residual effects, respectively;

$\sigma_{12}=$ covariance between sire and MGS effects;

$\mathbf{A}=$ numerator relationship matrix among bulls which included both sires and MGS. In total, 10348 pedigree bulls over 5 generations were generated from 9400 bulls represented in the data. The relationships between dams were ignored.

The corresponding mixed model equations after absorption of fixed effects were:

$$
\left[\begin{array}{ccc}
\mathbf{Z}_{1}^{\prime} \mathbf{M Z}_{1}+\mathbf{A}^{-1} k^{11} & \mathbf{Z}_{1}^{\prime} \mathbf{M Z}_{2}+\mathbf{A}^{-1} k^{12} & \mathbf{Z}_{1}^{\prime} \mathbf{M Z}_{3} \\
\mathbf{Z}_{2}^{\prime} \mathbf{M Z}_{1}+\mathbf{A}^{-1} k^{12} & \mathbf{Z}_{2}^{\prime} \mathbf{M Z}_{2}+\mathbf{A}^{-1} k^{22} & \mathbf{Z}_{2}^{\prime} \mathbf{M} \mathbf{Z}_{3} \\
\mathbf{Z}_{3}^{\prime} \mathbf{M} \mathbf{Z}_{1} & \mathbf{Z}_{3}^{\prime} \mathbf{M} \mathbf{Z}_{2} & \mathbf{Z}_{3}^{\prime} \mathbf{M Z}_{3}+\mathbf{I} k^{33}
\end{array}\right]\left[\begin{array}{c}
\widehat{\mathbf{u}}_{1} \\
\widehat{\mathbf{u}}_{2} \\
\widehat{\mathbf{u}}_{3}
\end{array}\right]=\left[\begin{array}{c}
\mathbf{Z}_{1}^{\prime} \mathbf{M y} \\
\mathbf{Z}_{2}^{\prime} \mathbf{M y} \\
\mathbf{Z}_{3}^{\prime} \mathbf{M y}
\end{array}\right]
$$

where:

$$
\begin{gathered}
\mathbf{M}=\mathbf{I}-\mathbf{X}\left(\mathbf{X}^{\prime} \mathbf{X}\right)^{-} \mathbf{X}^{\prime} ; \\
{\left[\begin{array}{ccc}
k^{11} & k^{12} & 0 \\
k^{12} & k^{22} & 0 \\
0 & 0 & k^{33}
\end{array}\right]=\left[\begin{array}{ccc}
\sigma_{1}^{2} & \sigma_{12} & 0 \\
\sigma_{12} & \sigma_{2}^{2} & 0 \\
0 & 0 & \sigma_{3}^{2}
\end{array}\right]^{-1} \times \sigma_{\mathbf{e}}^{2}}
\end{gathered}
$$

The tilde-hat approach of Van Raden and Jung (1988) involves quadratics which are functions of solutions and approximate solutions for the random effects of the mixed model equations [1]. The approximate solutions were obtained by (Bertrand and Benyshek, 1987):

$$
\left[\begin{array}{c}
\widetilde{\mathbf{u}}_{1} \\
\widetilde{\mathbf{u}}_{2} \\
\widetilde{\mathbf{u}}_{3}
\end{array}\right]=\left[\begin{array}{ccc}
\mathbf{D}_{11} & \mathbf{D}_{12} & \mathbf{0} \\
\mathbf{D}_{12} & \mathbf{D}_{22} & \mathbf{0} \\
\mathbf{0} & \mathbf{0} & \mathbf{D}_{33}
\end{array}\right]^{-1}\left[\begin{array}{l}
\mathbf{Z}_{1}^{\prime} \mathbf{M y} \\
\mathbf{Z}_{2}^{\prime} \mathbf{M y} \\
\mathbf{Z}_{3}^{\prime} \mathbf{M y}
\end{array}\right]=\left[\begin{array}{ccc}
\mathbf{D}^{11} & \mathbf{D}^{12} & \mathbf{0} \\
\mathbf{D}^{12} & \mathbf{D}^{22} & \mathbf{0} \\
\mathbf{0} & \mathbf{0} & \mathbf{D}^{33}
\end{array}\right]\left[\begin{array}{l}
\mathbf{Z}_{1}^{\prime} \mathbf{M y} \\
\mathbf{Z}_{2}^{\prime} \mathbf{M y} \\
\mathbf{Z}_{3}^{\prime} \mathbf{M y}
\end{array}\right]
$$

where $\mathbf{D}_{11}, \mathbf{D}_{12}, \mathbf{D}_{22}$ and $\mathbf{D}_{33}$ are diagonal matrices with diagonal elements identical to those of the matrices $\mathbf{Z}_{1}^{\prime} \mathbf{M} \mathbf{Z}_{1}+\mathbf{A}^{-1} k^{11}, \mathbf{Z}_{1}^{\prime} \mathbf{M} \mathbf{Z}_{2}+\mathbf{A}^{-1} k^{12}, \mathbf{Z}_{2}^{\prime} \mathbf{M} \mathbf{Z}_{2}+$ $\mathbf{A}^{-1} k^{22}$ and $\mathbf{Z}_{3}^{\prime} \mathbf{M} \mathbf{Z}_{3}+\mathbf{I} k^{33}$, respectively.

In fact, the diagonals of matrix $\mathbf{Z}_{1}^{\prime} \mathbf{Z}_{2}$ were zero due to removal of calves having the same bull as sire and MGS. However, those of $\mathbf{Z}_{1}^{\prime} \mathbf{M} \mathbf{Z}_{2}\left(\mathbf{Z}_{1}^{\prime} \mathbf{Z}_{2}\right.$ after absorption of fixed effects) were not equal to zero.

The general formula for a model with $p$ possibly correlated random effects is:

$$
\mathbf{E}\left(\widehat{\mathbf{u}}_{i}^{\prime} \mathbf{A}^{-1} \widetilde{\mathbf{u}}_{j}\right)=\operatorname{tr}\left(\sum_{h=1}^{p} \sum_{k=1}^{p} \mathbf{D}^{j k} \mathbf{Z}_{k}^{\prime} \mathbf{M} \mathbf{Z}_{h} \sigma_{i h}\right)
$$

where: $i, j, h$ and $k=1,2, \ldots, p$, ie the number of random effects in the model.

For the model assumed in this study, 5 quadratics $\left(\widehat{\mathbf{u}}_{1}^{\prime} \mathbf{A}^{-1} \widetilde{\mathbf{u}}_{1}^{\prime}, \widehat{\mathbf{u}}_{1}^{\prime} \mathbf{A}^{-1} \widetilde{\mathbf{u}}_{2}\right.$, $\widehat{\mathbf{u}}_{2}^{\prime} \mathbf{A}^{-1} \widetilde{\mathbf{u}}_{1}, \widehat{\mathbf{u}}_{2}^{\prime} \mathbf{A}^{-1} \widetilde{\mathbf{u}}_{2}$ and $\widehat{\mathbf{u}}_{3}^{\prime} \widetilde{\mathbf{u}}_{3}$ ) were used to estimate 4 (co)variance components $\left(\sigma_{1}^{2}, \sigma_{12}, \sigma_{2}^{2}\right.$, and $\left.\sigma_{3}^{2}\right)$. As more quadratics were available than unknown variance components the least squares approach was used.

The residual variance $\left(\sigma_{\mathbf{e}}^{2}\right)$ was estimated by the following formula:

$$
\widehat{\sigma}_{\mathbf{e}}^{2}=\left(\mathbf{y}^{\prime} \mathbf{M} \mathbf{y}-\widehat{\mathbf{u}}_{1}^{\prime} \mathbf{Z}_{1}^{\prime} \mathbf{M} \mathbf{y}-\widehat{\mathbf{u}}_{2}^{\prime} \mathbf{Z}_{2}^{\prime} \mathbf{M y}-\widehat{\mathbf{u}}_{3}^{\prime} \mathbf{Z}_{3}^{\prime} \mathbf{M y}\right) /(N-r(\mathbf{X})) .
$$


where:

$N=$ total number of observations in the analyses;

$r(\mathbf{X})=$ rank of matrix $\mathbf{X}$.

The tilde-hat procedure requires only the diagonals of the coefficient matrix in equations [1] for (co)variance estimation. Consequently, the mixed model equations were not explicitly constructed, and solutions for random effects in equations [1] were obtained by the direct iteration approach on data (Schaeffer and Kennedy, 1986; Mandredi, 1990; Mandredi et al, 1991). Thus, 2 levels of nested iterations were involved for the analyses. Solutions for fixed and random effects were first obtained from the inner iterations. After 15 iterations or when the convergence criterion attained $10^{-7}$, the outer iteration was then implemented for the estimation of the variance components. Iteration was finally stopped after a value of $10^{-7}$ for convergence was reached. The criterion of convergence $(\theta)$ was calculated as follows:

$$
\theta=\sqrt{\sum_{i=1}^{n}\left(\phi_{i}^{(k+1)}-\phi_{i}^{k}\right)^{2} / \sum_{i=1}^{n}\left(\phi_{i}^{(k+1)}\right)^{2}}
$$

where:

$\phi_{i}=$ solutions for fixed and random effects for the inner iteration, and variance components for the outer interation;

$k=$ number of iterations;

$n=$ total levels for fixed and random effects in the inner iteration, and is 5 for the outer iteration.

The expectations of the (co)variances estimated from model [1] were as follows:

$$
\begin{aligned}
& E\left(\sigma_{1}^{2}\right)=(1 / 4) \sigma_{A}^{2} \\
& E\left(\sigma_{2}^{2}\right)=(1 / 16) \sigma_{A}^{2}+(1 / 4) \sigma_{A M}+(1 / 4) \sigma_{M}^{2} \\
& E\left(\sigma_{3}^{2}\right)=(3 / 16) \sigma_{A}^{2}+(3 / 4) \sigma_{A M}+(3 / 4) \sigma_{M}^{2}+\sigma_{C}^{2} \\
& E\left(\sigma_{e}^{2}\right)=(1 / 2) \sigma_{A}^{2}+\sigma_{E}^{2} \\
& E\left(\sigma_{12}\right)=(1 / 8) \sigma_{A}^{2}+(1 / 4) \sigma_{A M}
\end{aligned}
$$

where:

$\sigma_{A}^{2}$ and $\sigma_{M}^{2}=$ genetic variances of direct and maternal effects, respectively;

$\sigma_{A M}=$ covariance between direct and maternal genetic effects;

$\sigma_{C}^{2}=$ variance of maternal permanent environmental effects;

$\sigma_{E}^{2}=$ variance of environmental effects. 
The genetic and environmental parameters were estimated as:

$$
\begin{aligned}
\sigma^{2} & =\sigma_{A}^{2}+\sigma_{A M}+\sigma_{M}^{2}+\sigma_{C}^{2}+\sigma_{E}^{2} ; \\
h_{A}^{2} & =\sigma_{A}^{2} / \sigma^{2} \\
h_{M}^{2} & =\sigma_{M}^{2} / \sigma^{2} \\
c^{2} & =\sigma_{C}^{2} / \sigma^{2} \\
h_{T}^{2} & =\left(\sigma_{A}^{2}+1.5 \sigma_{A M}+0.5 \sigma_{M}^{2}\right) / \sigma^{2} ; \\
r_{A M} & =\sigma_{A M} / \sigma_{A} \sigma_{M} ; \\
r_{S M G S} & =\sigma_{12} / \sigma_{1} \sigma_{2} ;
\end{aligned}
$$

where $\sigma^{2}$ is the total phenotypic variance, $h_{A}^{2}$ is the direct heritability, $h_{M}^{2}$ is the maternal heritability and $h_{T}^{2}$ is the total heritability as defined by Dickerson (1947), $c^{2}$ is the proportion of phenotypic variance imputable to the maternal permanent environmental effects, $r_{A M}$ is the correlation between direct and maternal additive genetics effects, $r_{S M G S}$ is the correlation between sire and maternal grandsire effects.

\section{RESULTS AND DISCUSSION}

Table III and table IV show estimates of (co)variances and estimates of heritabilities and correlations, respectively.

Table III. Variance and covariance estimates ${ }^{a}$ for preweaning growth and conformation at weaning in French Limousin breed.

\begin{tabular}{lccccr}
\hline Traits & Sire & MGS & Cov & Dam & Res \\
\hline Weights (kg): & & & & & \\
$\quad$ Birth weight & 0.53 & 0.16 & 0.16 & 0.79 & 5.3 \\
120-d weight & 15.1 & 10.1 & 4.7 & 47.3 & 158.9 \\
210-d weight & 34.1 & 19.6 & 11.2 & 102.1 & 361.8 \\
Average daily gains (g/d): & & & & & \\
G $_{0-120}^{\text {Gi20-210 }}$ & 883 & 637 & 275 & 3018 & 10520 \\
G $_{0-210}$ & 968 & 269 & 227 & 1729 & 14401 \\
Conformation (total score / 100): & 697 & 412 & 222 & 2192 & 7898 \\
$\quad$ Muscular development & 3.67 & 0.98 & 1.16 & 4.28 & 36.91 \\
$\quad$ Skeletal development & 2.43 & 0.69 & 0.78 & 3.46 & 24.46 \\
\hline
\end{tabular}

a Sire, MGS, Dam, and Res represent sire, maternal grandsire, dam, and residual effects, respectively. Cov is the covariance between sire and MGS effects. 
Table IV. Estimates of genetic parameters for preweaning growth and conformation at weaning in French Limousin breed.

\begin{tabular}{|c|c|c|c|c|c|c|}
\hline \multirow[t]{2}{*}{ Traits } & \multicolumn{3}{|c|}{ Heritability } & \multirow[b]{2}{*}{$\begin{array}{c}\mathrm{b} \\
\mathrm{c}^{2}\end{array}$} & \multicolumn{2}{|c|}{ Correlation } \\
\hline & $\mathrm{h}_{\mathrm{A}}^{\mathbf{a}}$ & $\mathrm{h}_{\mathrm{M}}^{\mathrm{a}}$ & $\mathrm{h}_{\mathrm{T}}^{2}$ & & $\begin{array}{c}\text { c } \\
\mathrm{r}_{\mathrm{SMGS}}\end{array}$ & $\begin{array}{c}\mathrm{c} \\
\mathrm{r}_{\mathrm{AM}}\end{array}$ \\
\hline $\begin{array}{l}\text { Weights: } \\
\text { Birth weight } \\
\text { 120-d weight } \\
\text { 210-d weight }\end{array}$ & $\begin{array}{l}0.31 \\
0.26 \\
0.26\end{array}$ & $\begin{array}{l}0.08 \\
0.16 \\
0.13\end{array}$ & $\begin{array}{l}0.26 \\
0.27 \\
0.26\end{array}$ & $\begin{array}{l}0.05 \\
0.07 \\
0.08\end{array}$ & $\begin{array}{l}0.55 \\
0.38 \\
0.43\end{array}$ & $\begin{array}{l}-0.40 \\
-0.24 \\
-0.24\end{array}$ \\
\hline $\begin{array}{l}\text { Average daily gains: } \\
\mathrm{G}_{0-120} \\
\mathrm{G}_{120-210} \\
\mathrm{G}_{0-210}\end{array}$ & $\begin{array}{l}0.23 \\
0.22 \\
0.25\end{array}$ & $\begin{array}{l}0.15 \\
0.07 \\
0.13\end{array}$ & $\begin{array}{l}0.25 \\
0.17 \\
0.25\end{array}$ & $\begin{array}{l}0.07 \\
0.05 \\
0.09\end{array}$ & $\begin{array}{l}0.37 \\
0.44 \\
0.41\end{array}$ & $\begin{array}{l}-0.23 \\
-0.49 \\
-0.25\end{array}$ \\
\hline $\begin{array}{l}\text { Conformation: } \\
\text { Muscular development } \\
\text { Skeletal development }\end{array}$ & $\begin{array}{l}0.32 \\
0.31\end{array}$ & $\begin{array}{l}0.06 \\
0.07\end{array}$ & $\begin{array}{l}0.26 \\
0.26\end{array}$ & $\begin{array}{l}0.03 \\
0.04\end{array}$ & $\begin{array}{l}0.61 \\
0.60\end{array}$ & $\begin{array}{l}-0.41 \\
-0.38\end{array}$ \\
\hline
\end{tabular}

a $A, M$ and $T$ represent direct and maternal genetic effects and total heritable genetic effects, respectively; ${ }^{\mathrm{b}} c^{2}$ is the ratio of maternal permanent environmental variance to the total phenotypic variance; ${ }^{\mathrm{c}} r_{S M G S}$ and $r_{A M}$ are correlations between sire and $M G S$, and between direct and maternal genetic effects, respectively.

\section{Direct and maternal parameters for preweaning growth traits}

Estimates of direct heritabilities of birth and weaning weights and preweaning gain from birth to weaning $\left(h_{A}^{2}=0.31,0.26\right.$ and 0.25 , respectively) were in close agreement with the median values of literature surveys (Petty and Cartwright, 1966; Baker, 1980; Meyer, 1992; Renand et al, 1992) but higher than values reported in the North American Limousin breed (0.22 and 0.16 for birth and weaning weights, respectively; Bertrand and Benyshek, 1987).

Maternal heritability estimates in this study were lower than direct heritabilities of the corresponding traits $\left(h_{M}^{2}=0.08,0.13\right.$ and 0.13 , respectively). Most literature estimates for maternal genetic heritability ranged from 0.05 to 0.25 for birth weight, and 0.10 to 0.35 for preweaning gain or weaning weight (Quaas et al, 1985; Bertrand and Benyshek, 1987; Wright et al, 1987; Trus and Wilton, 1988; Garrick et al, 1989; Kriese et al, 1991; Ménissier and Frisch, 1992; Meyer, 1992). The present estimates for maternal genetic effects in French Limousin breed were in the lower tail of the ranges.

The estimates of the ratio between the maternal permanent environmental variances and the phenotypic variances were small in the French Limousin breed, ranging from 0.05 to 0.09 . These values were in accordance with the reports given by Bertrand and Benyshek (1987), Wright et al (1987) and Meyer (1992).

Correlation estimates between direct and maternal genetic effects were found to be negative in this study (table IV) and in accordance with the estimates in the 
North American Limousin breed $\left(r_{A M}=-0.16\right.$ and -0.30 for birth and weaning weights, respectively; Bertrand and Benyshek, 1987). Moreover, the majority of reports in the literature indicated negative $r_{A M}$ of similar traits (Ménissier, 1976; Quaas et al, 1985; Bertrand and Benyshek, 1987; Cantet et al, 1988; Trus and Wilton, 1988; Garrick et al, 1989; Kriese et al, 1991; Ménissier and Frisch, 1992; Meyer, 1992). These estimates frequently ranged from 0 to -0.5 However, some positive direct-maternal genetic correlations were also reported (Wright et al, 1987; Northcutt et al, 1991; Trus and Wilton, 1988; Meyer, 1992).

As a matter of fact, considerable variation exists in the literature estimates of direct and maternal effects and their covariance components. This can be attributed to a number of factors, $e g$ methods of estimation, statistical models, data resources (experimental or field data, breeds and production systems), assortive matings or previous selection. On the other hand, even with the most realistic model, the maternal animal model, some effects were always assumed to be absent due to computational limitation. For instance, a covariance between maternal and direct environments may exist (resulting from side effects of high nutrition during rearing of heifers on their milk ability; Mangus and Brinks, 1971) and consequently may bias the estimation of covariance between direct and maternal genetic effects (Koch, 1972; Baker, 1980; Willham, 1980; Canter et al, 1988). Otherwise, relatively large sampling variances of the estimates could exist for maternally influenced traits (Thompson, 1976; Foulley and Lefort, 1978; Cantet, 1990; Meyer, 1992).

Weaning weights of beef calves depend primarily upon the joint expression of preweaning growth potential of calves and maternal traits (primarily the milk production) of their dams. The relative importance of direct and maternal effects on growth may be better expressed by the estimates for preweaning growth rate $\left(\mathrm{G}_{0-120}, \mathrm{G}_{120-210}\right.$ or 120 -d weight. The estimates for both direct and maternal effects of 120 -d weight were very similar to those of 210 -d weight, with maternal effects being slightly more important for 120 -d weight (table IV). This is realistic since calves are able to eat supplemental feed at the later stage of lactation. As shown by Neville (1962) and Le Neindre et al (1976), milk production was more important during the early period of the calf's life, and declined slightly up to weaning. A much lower direct heritability was obtained using a dam-offspring relationship by Molinuevo and Vissac (1972) in the same breed. This confirms the negative relationship between direct and maternal effects. The estimates for $\mathrm{G}_{0-120}$ were very similar to those of 120 -d weight for both heritabilities for, and correlation between direct and maternal effects. For the growth period from $120 \mathrm{~d}$ to $210 \mathrm{~d}$, however, the maternal genetic variation had been greatly reduced compared to the earlier period of growth (table III) and consequently maternal heritability was lower $\left(h_{M}^{2}=0.07\right)$ than for $\mathrm{G}_{0-120}\left(h_{M}^{2}=0.15\right)$. It was the only trait with different (lower) total heritability (table IV). The maternal influence of 210-d weight was apparently a carry-over effect. Rutledge et al (1971) reported that when measures of milk yield for the first 4 months were in the model, inclusion of measures from the remaining 3 months did not lead to a significant reduction in the residual sum of squares. Further, the antagonism between direct and maternal effects was stronger in the later period of growth (table IV). This fact might be induced by more pronounced interaction between environmental factors (maternal, calf feed supplies) and calf growth compensation, for which interaction might contribute to 
the inflated negative covariance between maternal and direct environments that is always assumed to be zero in models. As suggested by Robison (1981), calves from dams producing less milk are forced to seek supplemental feed earlier which may over-compensate for the extra milk production by other dams. Such overcompensation is as important as the calf becomes older and concentrate is supplied. Moreover, especially for the growth period of 120 -d to $210-d$, the estimated ratio between maternal permanent environmental variances and phenotypic variances was small (table IV).

\section{Direct and maternal parameters for conformation at weaning}

The results of this study showed that MD and SD were moderately heritable and mainly controlled by direct genetic effects rather than maternal genetic effects (table IV). The present direct heritabilities of MD and SD were similar to the estimates of Laloë et al (1988) in French Limousin cattle. For overall conformation score at weaning, Petty and Cartwright (1966) reported an average value of 0.36 of direct genetic heritability from 24 estimates. The same value was obtained by Vesely and Robison (1971) for Hereford cattle.

Due to the antagonism between direct and maternal genetic effects, the total heritabilities for both MD and SD were slightly reduced. Moderate heritabilities indicate that direct selection for conformation at weaning should be efficient. However, a small negative response of the maternal ability will result. Muscularity is desirable for carcass quality. However, improved muscularity may lead to a deterioration of maternal calving ability due to the late maturing rate of the pelvic opening (Ménissier and Frisch, 1992).

The estimates of the ratio between the maternal permanent environmental variances and the phenotypic variances were smaller for both conformation traits (0.03 to 0.04 ) than for weights or preweaning gain.

\section{CONCLUSION}

The preweaning growth genetic parameters in this study show that the growth genetic variability is different for different growth stages. Foetal growth, measured by birth weight, is largely influenced by direct genetic effects, with an important foeto-maternal regulation as shown by a negative genetic correlation between direct and maternal effects. Otherwise, maternal effects are more important for early growth after birth, with a still negative but lower genetic correlation between direct and maternal effects. Close to weaning, maternal influences are smaller for growth, and, similarly, beef conformation at weaning is largely controlled by direct genetic effects.

From a selection point of view, weaning weight or growth to weaning is heritable enough to allow an efficient selection for direct genetic effects, ie for the calf's growth ability. However, selection solely for direct genetic effects does not lead to improvement of the cow's maternal ability, and could even result in deterioration of the maternal ability because of the negative correlation between maternal and direct genetic effects. Selection for combination of direct and maternal effects is necessary for the genetic improvement of beef cattle used both as sire and pure 
breeds such as the French Limousin cattle. The maternal genetic parameters of the different preweaning growth stages show that, among the analysed traits, $120 \mathrm{~d}$ weight or growth from birth to $120 \mathrm{~d}$ is a good selection criterion for carrying out a joint selection on cows' suckling ability (maternal effects) and calve's growth capacity (direct effects).

On the other hand, it is essential to have estimates of genetic correlations between traits for both maternal and direct effects, in order to optimize the choice of measurements and selection criteria for preweaning growth.

\section{ACKNOWLEDGMENT}

Support of this research by a grant from the INRA is gratefully acknowledged.

\section{REFERENCES}

Baker RL (1980) The role of maternal effects on the efficiency of selection in beef cattle: a review. Proc NZ Soc Anim Prod 40, 285-303

Bertrand JK, Benyshek LL (1987) Variance and covariance estimates for maternally influenced beef growth traits. J Anim Sci 64, 728-734

Cantet RJC, Kress DD, Anderson DC, Doornbos DE, Burfening PJ, Blackwell RL (1988) Direct and maternal variances and covariances and maternal phenotypic effect on preweaning growth of beef cattle. J Anim Sci 66, 648-660

Cantet RJC (1990) Estimation and prediction problems in mixed linear models for maternal genetic effects. Ph D Diss, Univ Illinois, Urbana, IL

Dickerson GE (1947) Composition of hog carcasses as influenced by heritable differences in rate and economy of gain. Iowa Agric Exp Sta Res Bull 354, 489524

FNOCPAB-ITEB (1983) Le Règlement Technique du Contrôle des Performances Bouchères (Vaches Allaitantes). FNOCPAB-ITEB, France, edn 1983

Foulley JL, Lefort G (1978) Méthodes d'estimation des effets directs et maternels en sélection animale. Ann Génét Sél Anim 10, 475-496

Garrick DJ, Pollak JE, Quaas RL, Van Vleck LD (1989) Variance heterogeneity in direct and maternal weight traits by sex and percent pour breed for Simmental-sired calves. J Anim Sci 67, 2515-2528

Harville DA (1977) Maximum likelihood approaches to variance component estimation and to related problems. J Am Stat Soc 72, 320-338

Henderson CR (1973) Sire evaluation and genetic trends. In: Proc Anim Breed and Genet Symp in Honor of Dr Jay L Lush. Am Soc Anim Sci and Am Dairy Sci Assoc, Champaign, IL, pp 10

Henderson CR (1980) A simple method for unbiased estimation of variance components in the mixed model. J Anim Sci 51 (suppl 1), 119 (abstr 34)

Koch RM (1972) The role of maternal effects in animal breeding: VI. Maternal effects in beef cattle. J Anim Sci 35, 1316-1337

Kriese LA, Bertrand JK, Benyshek LL (1991) Genetic and environmental growth trait parameter estimates for Brahman and Brahman-derivative cattle. J Anim Sci $69,2362-2370$ 
Laloë D, Renand G, Ménissier F, Astruc JM, Gaillard J, Sapa J (1988) Genetic parameters among preweaning calf performance for beef breeds in French field record programs. In: Proc 3rd World Congr Sheep and Beef Cattle Breeding. Paris, 1988, June, 19-23, vol 1, 355-358

Le Neindre P, Petit M, Tomassone R, Roux C (1976) Production laitière des vaches allaitantes et croissance de leurs veaux: I. Race Limousine. Ann Zootech 25, 221-224 Manfredi E (1990) Analyse génétique des conditions de naissance chez les bovins par le modèle à seuil. Thèse, Univ de Paris-Sud Orsay, France, 245 pp

Manfredi E, Ducrocq V, Foulley JL (1991) Genetic analysis of dystocia in dairy cattle. J Dairy Sci 74, 1715-1723

Mangus WL, Brinks JS (1971) Relationships between direct and maternal effects on growth in Herefords: I Environmental factors during preweaning growth. J Anim Sci $32,17-25$

Ménissier F (1976) Comments on optimization of cattle breeding schemes: beef breeds for suckling herds a review. Ann Génét Sél Anim 8, 71-87

Ménissier F, Frisch JE (1992) Genetic improvement of beef cows. In: Beef Cattle Production (Jarrige R, ed) Elsevier, Amsterdam, World Animal Ser, ch 3, vol C5, 55-85

Meyer K (1990) Present status of knowledge about statistical procedures and algorithms to estimate variance and covariance components. Proc 4th World Congr Genetics Appl Livest Prod. Edinburgh, July 23-27, 1990, vol XIII, 407-418

Meyer K (1992) Variance components due to direct and maternal effects for growth traits of Australian beef cattle. Livest Prod Sci 31, 179-204

Molinuevo HA, Vissac B (1972) Variabilité génétique de la croissance avant sevrage dans les races Charolaise et Limousine. Ann Génét Sél Anim 4, 423-444

Neville Jr WE (1962) Influence of dam's milk production and other factors on 120and 240-day weight of Hereford calves. J Anim Sci 21, 315-320

Northcutt SL, Willham RL, Wilson DE (1991) Genetic parameters for nuclear and nonnuclear inheritance in three synthetic lines of beef cattle differing in mature size. J Anim Sci $69,4745-4753$

Ouweltjes W, Schaeffer LR, Kennedy BW (1988) Sensitivity of methods of variance components estimation to culling type of selection. J Dairy Sci 71, 773-779

Patterson HD, Thompson R (1971) Recovery of inter-block information when block sizes are unequal. Biometrika 58, 545-554

Petty Jr RR, Cartwright TC (1966) A summary of genetic and environmental statistics for growth and conformation traits of young beef cattle. In: Departmental Technical Report No 5. Dept Anim Sci, Texas A \& M Univ, TX

Quaas RL, Elzo MA, Pollak EJ (1985) Analysis of Simmental data: Estimation of direct and maternal (co)variances. J Anim Sci 61 suppl 1, 221, abstr 34

Renand G, Plasse D, Andersen BB (1992) Genetic improvement for growth and carcass traits. In: Beef Cattle Production (Jarrige R, ed) Elsevier, Amsterdam, World Animal Ser, ch 4, vol C5, 86-107

Robison OW (1981) The influence of maternal effects on the efficiency of selection: a review. Livest Prod Sci 8, 121-137

Rutledge JJ, Robison OW, Ahlschwede WJ, Legates (1971) Milk yield and its influence on 205-day weight of beef calves. J Anim Sci 33, 563-567 
Schaeffer LR (1986) Pseudo expectation approach to variance component estimation. J Dairy Sci 69, 2884-2889

Schaeffer LR, Kennedy BW (1986) Computing solutions to mixed model equations. In: Proc 3rd World Congr on Genet Appl Livest Prod. Lincoln, Nebraska, July 1622, 1986, vol XII, 382-393

Shi JM, Laloë D (1991) Comparison of two methods for variances and covariances estimation for maternally influenced traits applied to French beef cattle field data. In: 42nd Annu Meet Eur Assoc Anim Prod. Berlin, Germany, September 9-12: Commission on Animal Genetics, 162-163

Sorensen DA, Kennedy BW (1984) Estimation of genetic variances from unselected and selected populations. J Anim Sci 59, 1213-1223

Thompson R (1976) The estimation of maternal genetic variances. Biometrics 32, 903-917

Trus D, Wilton JW (1988) Genetic parameters for maternal traits in beef cattle. Can J Anim Sci 68, 119-128

Van Raden PM, Jung YC (1988) A general purpose approximation to restricted maximum likelihood: the tilde-hat approach. J Dairy Sci 71, 187-194

Vesely JA, Robison OW (1971) Genetic and maternal effects on preweaning growth and type score in beef calves. J Anim Sci 32, 825-831

Werf JHJ van der, de Boer IJM (1990) Estimation of additive genetic variance when base populations are selected. J Anim Sci 68, 3124-3132

Willham RL (1980) Problems in estimating maternal effects. Livest Prod Sci 7, 405-418

Wright HB, Pollak EJ, Quaas RL (1987) Estimation of variance and covariance components to determine heritabilities and repeatability of weaning weight in American Simmental cattle. J Anim Sci 65, 975-981 